\title{
PENGARUH KUALITAS LAYANAN DAN KUALITAS PRODUK TERHADAP KEPUASAN NASABAH BANK TABUNGAN NEGARA CABANG KARAWANG
}

\author{
Nur Fitria Umar 1) \\ 1) Mahasiswa Program Studi Manajemen FE UNKRIS \\ Nuridin 2) \\ 2) Dosen Program Studi Manajemen FE UNKRIS \\ Alamat: Kampus UNKRIS, Jatiwaringin Jakarta Timur \\ Email : h.nuridin58@gmail.com
}

\begin{abstract}
To determine the effect of service quality and product quality on Customer Satisfaction at Bank Tabungan Negara, Karawang Branch. This research is included in the category of causal associative research using a quantitative approach. The population in this study were the customers of Bank Tabungan Negara, Karawang Branch, with the criteria being at least 17 years old, with a sample of 80 people with incidental sampling techniques. Methods of data analysis using partially and simultaneous linear regression. The results showed that partially or simultaneous service quality and product quality had a positive and significant effect on customer satisfaction at Bank Tabungan Negara, Karawang Branch.
\end{abstract}

Keywords: Service quality, product quality and customer satisfaction

\section{PENDAHULUAN}

Dewasa ini dunia telah memasuki masa persaiangan bebas dimana perbankan merupakan bagian penting dari sistem keuangan guna kelancaran kegiatan perekonomian suatu negara. Hal tersebut mendorong adanya pengembangan negara keluar negeri hal ini menyebabkan persaingan dunia usaha semakin ketat termasuk dunia perbankan. Untuk memenangkan persaingan maka di butuhkan adanya inovasi produk salah satunya pengembangan tekhnologi informasi. Pentingnya teknologi informasi dalam bisnis tidak diragukan lagi. Banyak perusahaan di dunia berkeinginan untuk mengubah dirinya menjadi pembangkit daya (power house) bisnis global melalui berbagai investasi besar dalam e-business, e-commerce, dan usaha Teknologi Informasi (TI) lainnya yang global.

Teknologi informasi adalah suatu teknologi yang digunakan untuk mengolah data, termasuk memproses, mendapatkan, menyusun, menyimpan, memanipulasi data dalam berbagai cara untuk menghasilkan informasi yang berkualitas, yaitu informasi yang relevan, akurat dan tepat waktu, yang digunakan keperluan pribadi, bisnis, dan pemerintahandan merupakan informasi yang strategis untuk pengambilan keputusan.

Dalam kegiatan industri modern saat ini, tingkat mobilitas dan kesibukan yang semakin meningkat mengakibatkan banyak orang membutuhkan alat yang bisa dengan cepat dan tepat dalam pemenuhan kebutuhannya. Dalam dunia perbankan di era tahun 1990-an kita diperkenalkan dengan adanya sistem perbankan modern yaitu kita diperkanlkan dengan transaksi Automatic Teller Machine atau yang lebih sering disingkat dengan ATM. Namun kehadiran ATM 
saat ini masih dirasa ketinggalan, dimana orang harus mencari keberadaan ATM yang sesuai dengan bank dimana ia menyimpan uangnya.

Perkembangan teknologi informasi, telekomunikasi di dunia sudah berkembang sangat pesat dan internet merupakan salah satu perkembangan yang sangat menonjol, ini memungkinkan basis usaha saat ini menggunakan internet. Salah satu aplikasi yang mulai mendapat perhatian adalah internet banking.

Populasi pengguna internet di Indonesia berkembang sangat pesat. Hasil survei Asosiasi Penyelenggara Jasa Internet Indonesia (APJII) periode 2019kuartal II/2020 mencatat, jumlah pengguna internet di Indonesia mencapai 196,7 juta jiwa. Jumlah ini meningkat 23,5 juta atau 8,9\% dibandingkan pada 2018 lalu. Riset dilakukan pada 2-25 Juni 2020. (databoks.katadata.co.id > data publish > 2020/11/11 > jum).

Oleh karena itu dalam dunia perbankan saat ini dikembangkanlah Internet Banking yang mempunyai tujuan sebagai fasilitas bagi para nasabahnya dalam rangka menjalankan kegiatan keuangannya. Kemajuan dibidang teknologi ini akan mempermudah nasabah untuk bertransaksi dimanapun mereka berada tanpa perlu harus mengantri panjang untuk melakukan transaksi dengan kecanggihan teknologi yang ada saat ini yaitu dengan bertransaksi melalui Internet Banking atau yang lebih dikenal E-Banking (Helza, 2007).

\section{E-Banking}

merupakan penghantaran otomatis jasa dan produk bank secara langsung kepada nasabah melalui media elektronik serta saluran komunikasi interaktif. E-Banking merupakan sistem yang memungkinkan nasabah bank, baik individu ataupun bisnis, mampu mengakses rekening, melakukan transaksi bisnis, atau mendapatkan informasi produk dan jasa bank melalui jaringan pribadi atau publik, termasuk internet.
Dalam perkembangannya, EBanking dipertimbangkan sebagai suatu strategi yang akan meningkatkan efisiensi, efektifitas dan produktifitas sekaligus meningkatkan pendapatan melalui sistem penjualan yang jauh lebih baik. Transaksi perbankan dengan menggunakan Electronic Banking (E-Banking) di Indonesia baik secara frekuensi maupun volume terus mengalami peningkatan. Untuk tahun 2014 saja volume E-Banking sudah mencapai Rp 6.447 triliun atau naik 17,32 persen dibanding tahun sebelumnya.

Dibandingkan layanan E-Banking lainnya, perkembangan Mobile Banking (M-Banking) terbilang paling cepat. Perkembangan ini hadir karena layanan $M$-Banking mampu menjawab kebutuhan masyarakat modern yang sangat mengedepankan kecepatan mobilitas. Dengan satu sentuhan, M-Banking menciptakan kemudahan layanan perbankan yng terbilang cukup komplek.

Hasil survei lembaga riset keuangan internasional mengungkapkan 35\% dari seluruh kegiatan online yang dilakukan di setiap rumah di seluruh dunia akan beralih ke layanan M-Banking. Diprediksi, nilai transaksi $M$-Banking akan naik dua kali lipat per tahun. Selanjutnya akan meningkat menjadi empat kali lipat setelah 2011. Saat ini hampir seluruh bank sudah mengaplikasikan layanan $m$ banking. Berdasarkan hasil riset MARS Indonesia yang dimuat dalam "Studi Pasar \& Perilaku Nasabah Mobile Banking 2008" ada 3 alasan utama mengapa nasabah bank membutuhkan layanan $\mathrm{m}$ banking, yaitu; (1) praktis karena tidak perlu datang ke bank/ATM (46,5\%), (2) transaksi menjadi lebih cepat $(32,7 \%)$, dan (3) mempermudah untuk cek saldo melalui $\operatorname{HP}(17,8 \%)$.

Faktor keamanan menjadi isu pokok dalam perkembangan E-Banking karena sebagaimana kegiatan lainnya seperti di internet, transaksi perbankan di internet juga rawan terhadap pengintaian 
dan penyalahgunaan oleh tangan-tangan yang tidak bertanggung jawab. Sebuah situs E-Banking diwajibkan untuk menggunakan standar keamanan yang sangat ketat untuk menjamin bahwa setiap layanan yang mereka sediakan hanya dimanfaatkan oleh nasabah yang memang betul-betul berhak. Beberapa teknik pengamanan yang biasanya digunakan oleh bank antara lain Penerapan teknologi Secure Socket Layer (SSL) 128 bit dan Secure HTTP (HTTPS), yang berfungsi mengenskripsi informasi yang dikirimkan pengguna. Sehingga, ketika terjadi man in the middle attack, informasi tetap aman dan tidak bisa dibaca oleh penyadap. Maka dari itu E-Banking yang mampu meyakinkan nasabahnya akan keamanan dan kerahasiaan data-data nasabah akan memperoleh loyalitas dari nasabah. (Muharsih, 2006).

Terdapat banyak faktor yang menyebabkan nasabah menaruh uang dibank pilihannya. Mulai dari kedekatan lokasi, layanan yang memuaskan, tingkat keamanan, fasilitas kemudahan transaksi, sampai dengan beberapa faktor lainnya. Namun, yang paling menarik untuk diperhatikan adalah faktor kualitas layanan. Berkaitan dengan kualitas layanan Internet banking dan kepuasan dalam penelitiannya Belibie (2012) mengungkapkan ada lima hal yang digunakan untuk mengetahui tingkat kualitas layanan yaitu, pertanggung jawaban keamanan, efesiensi transaksi, bantuan kepada pelanggan kemudahan penggunaan, perforna, konten layanan.

Masyarakat sebagai pengguna jasa kini semakin selektif dalam memilih bank untuk menitipkan dana yang dimiliki untuk menghindari risiko kehilangan dana akibat buruknya kinerja suatu Bank. Bagi perusahaan yang bergerak dibidang jasa perbankan, memuaskan nasabah adalah hal pokok yang tidak boleh diabaikan, dimana kepuasan nasabah merupakan aspek strategis dalam memenangkan persaingan mempertahankan citra perusahaan di masyarakat luas.

\section{Layanan internet banking} merupakan salah satu bentuk fasilitas perbankan yang sangat diminati nasabah perbankan di era globalisasi ini, nasabah perbankan saat ini lebih mobile, nasabah ingin mendapatkan pelayanan 24 jam / hari dan 7 hari perminggu, dimanapun mereka berada, inilah yang menjadikan Bank penyedia layanan internet banking lebih diminati oleh para langgan. Mengingat ketersedian internet banking merupakan salah satu bentuk pelayanan prima dari suatu bank maka perbankan harus memberikan akses internet banking yang baik pada para nasabahnya.

Selain faktor layanan kepada nasabah, faktor lain yang tidak kalah pentingnya terhadap kepuasan nasabah adalah kualitas produk dari suatu bank. Suatu produk dapat memuaskan nasabah bila dinilai dapat memenuhi atau melebihi keinginan dan harapan nasabah.

Kemampuan sebuah produk dalam memperagakan fungsinya, ini termasuk keseluruhan durabilitas, reliabilitas, ketepatan, kemudahan pengoperasian, dan reparasi produk, juga atribut produk lainnya. Faktor-faktor yang mempengaruhi kepuasan nasabah diantaranya adalah kualitas produk, kualitas produk, yang mempengaruhi kepuasan nasabah. Produk menjadi instrumen penting untuk mencapai kesuksesan dan kemakmuran pada perusahaan modern serta perbankan. Perkembangan teknologi, peningkatan persaingan global, serta kebutuhan dan keinginan pasar mengharuskan perusahaan ataupun perbankan melakukan pengembangan produk yang terus menerus.

Kualitas juga merupakan hal yang paling mendasar dari kepuasan nasabah dan kesuksesan dalam bersaing. Kepuasan pelanggan ditentukan oleh kualitas produk dan layanan yang dikehendaki pelanggan, sehingga jaminan kualitas menjadi 
kualitas utama bagi suatu perusahaan. Beberapa faktor yang dapat mempengaruhi kepuasan nasabah diantaranya adalah: keunggulan produk dan kualitas pelayanan nasabah. Kedua faktor tersebut mempengaruhi kepuasan nasabah pada suatu bank, dalam hal ini adalah Bank Tabungan Negara. Tbk. Cabang Karawang.

Hal sedang diupayakan proses perbaikan oleh Bank Tabungan Negara. Tbk. Cabang Karawang dalam meningkatkan kualitas layanan dan kualitas produk, seperti adanya inisiatif perbaikan dengan meningkatkan kegiatan cross selling khususnya dana low cost (Internal) dan melakukan role play $2 \mathrm{x}$ sehari (Eksternal), dilanjutkan dengan perbaikan WIG, yaitu meningkatkan jumlah NOA (Internal) dari $0-270$ periode waktu s/d 31 Desember 2020 (91 hari kerja) dan menyeragamkan standar layanan front liner untuk memberikan service excellent kepada nasabah (Eksternal), kemudian dengan lead measure; melakukan cross selling kepada setiap nasabah yang datang sesuai profil dengan alat ukur setiap Teller memiliki register cross selling, melakukan role play sebelum dan sesudah jam layanan dan real play secara konsisten dan meningkatkan pengetahuan mengenai produk knowledge dengan melakukan sosialisasi 1 kali dalam sebulan dan melakukan post test secara berkala.

Tabel 1 Proses Perbaikan Score Board Cross Selling

\begin{tabular}{|c|c|c|c|c|c|c|c|c|c|c|c|}
\hline \multirow{2}{*}{$\begin{array}{l}\text { Nama } \\
\text { Teller }\end{array}$} & \multicolumn{10}{|c|}{ Minggu } & \multirow{2}{*}{ Jumlah } \\
\hline & I & II & III & IV & $\mathbf{V}$ & VI & VII & VIII & IX & $\mathbf{X}$ & \\
\hline Ika & 0 & 2 & 1 & 3 & 3 & 2 & 2 & 1 & 2 & 1 & 14 \\
\hline Nur Fithfria & 5 & 16 & 24 & 18 & 18 & 12 & 21 & 22 & 22 & 14 & 145 \\
\hline Hidayach & 0 & 0 & 0 & 1 & 1 & 1 & 2 & 2 & 1 & 2 & 10 \\
\hline Riska S & 5 & 17 & 24 & 20 & 13 & 17 & 18 & 18 & 20 & 13 & 165 \\
\hline Jumlah & 10 & 35 & 49 & 42 & 30 & 32 & 43 & 45 & 45 & 30 & 337 \\
\hline
\end{tabular}

Sumber: data BTN, Cab. Karawang (2020)

Hasil akhir dari inisiatif ini adalah 1). Jumlah closing produk melebihi jumlah target yang sudah ditentukan. 2). Teller service sudah konsisten dalam melakukan role play dan real play sesuai dengan flow chart dari SQND. 3). Sebagian besar teller service konsisten dalam melakukan cross selling dan berhasil melakukan clossing di setiap harinya. 4). Saat teller service melakukan cross selling nasabah tertarik dengan produk-produk Bank BTN yang dijelaskan. 5). Nasabah merasa nyaman bertransaksi di Bank BTN karena pelayanan yang diberikan melebihi harapan pelanggan sehingga terciptanya customer experience.

Dampak insiatif terhadap kinerja tim adalah 1). Team teller selama 10 minggu dapat melakukan closing NOA
337 dan jumlah VOA yaitu Rp. 8.951.490.000,-. 2). Team teller telah terbiasa menjual produk jasa Bank BTN diantaranya Tabungan BATARA, BTN SIAP, Junior, Juara, Tabunganku, Prima, Deposito serta program yang berlangsung di Bank BTN.

Tujuan penelitian ini adalah untuk mengetahui pengaruh kualitas layanan dan kualitas produk terhadap kepuasan nasabah Bank Tabungan Negara Cabang Karawang.

\section{LANDASAN TEORI}

\section{Kepuasan Nasabah}

Kepuasan nasabah adalah perilaku emosional terhadap layanan yang diberikan oleh suatu bank, kemudian layanan yang diberikan dibandingkan 
dengan apa yang diharapkan (harapan sebelum kunjungan dengan apa yang diterima terhadap performa dan fasilitas).

Tjiptono dan Chandra (2012:), mengemukakan "kepuasan sebagai upaya pemenuhan sesuatu atau membuat sesuatu memadai". Kotler dan Keller (2012), menyampaikan "kepuasan sebagai perasaan senang atau kecewa seseorang yang dialami setelah membandingkan antara persepsi kinerja atau hasil suatu produk dengan harapan-harapannya". Biong dalam Yamit (2013), menjelaskan "kepuasan sebagai sebuah konsekuensi atau akibat atas pengalaman satu pihak terhadap kemampuan pihak lain untuk memenuhi norma-norma atau aturanaturan dengan harapan-harapannya”. Kepuasan disampaikan Muhmin dalam Yamit (2013), sebagai sebuah keadaan kasih sayang yang positif dihasilkan dari penilaian perusahaan terhadap seluruh aspek dari hubungan bekerjanya dengan perusahaan lain.

Dalam menentukan kepuasan ada lima faktor yang harus diperhatikan oleh perusahaan (Lupiyoadi, 2014) antara lain: 1). "Kualitas produk, yaitu konsumen akan merasa puas bila hasil mereka menunjukkan bahwa produk yang mereka gunakan berkualitas. 2). Kualitas produk atau jasa, yaitu konsumen akan merasa puas bila mereka mendapatkan layanan yang baik atau sesuai dengan yang diharapkan. 3). Emosi, yaitu konsumen akan merasa bangga dan mendapatkan keyakinan bahwa orang lain akan kagum terhadap dia bila menggunakan produk dengan merek tertentu yang cenderung mempunyai tingkat kepuasan yang lebih tinggi. Kepuasan yang diperoleh bukan karena kualitas dari produk tetapi sosial atau self esteem yang membuat pelanggan merasa puas terhadap merek tertentu. 4). Harga, yaitu produk yang mempunyai kualitas yang sama tetapi menetapkan harga yang relatif murah akan memberikan nilai yang lebih tinggi kepada konsumen. 5). Biaya, yaitu konsumen yang tidak perlu mengeluarkan biaya tambahan atau tidak perlu membuang waktu untuk mendapatkan suatu produk atau jasa cenderung puas terhadap produk atau jasa tersebut".

Kepuasan pelanggan merupakan konsekuensi dari perbandingan yang dilakukan oleh pelanggan yang membandingkan antara tingkatan dari manfaat yang dirasakan terhadap manfaat yang diharapkan oleh pelanggan. Adapun indikator kepuasan pelanggan menurut Swasta dan Irawan, (2008), yaitu: 1). "Perasaan puas (dalam arti puas akan produk dan pelayanannya), yaitu ungkapan perasaan puas atau tidak puas dari nasabah saat menerima layanan yang baik dan produk yang berkualitas dari bank. 2). Selalu membeli produk, yaitu nasabah akan tetap memakai dan terus membeli suatu produk apabila tercapainya harapan yang mereka inginkan. 3). Akan merekomendasikan kepada orang lain, yaitu nasabah yang merasa puas setelah memakai suatu produk atau jasa akan menceritakannya kepada orang lain serta mampu menciptakan nasabah baru bagi suatu bank. 4). Terpenuhinya harapan nasabah setelah membeli produk, yaitu sesuai atau tidaknya kualitas suatu produk atau jasa pasca pembelian suatu produk dengan harapan yang diinginkan nasabah".

\section{Kualitas Layanan}

Kualitas layanan menjadi suatu keharusan yang harus dilakukan perusahaan agar dapat mampu bertahan dan tetap mendapat kepercayaan nasabah. Pola konsumsi dan gaya hidup nasabah menuntut perusahaan mampu memberikan layanan yang berkualitas. Menurut Berry dan Zeithaml yang dalam Lupiyoadi (2014) berpendapat bahwa "Keberhasilan perusahaan dalam memberikan layanan yang berkualitas dapat ditentukan dengan pendekatan service quality". Service Quality adalah "seberapa jauh perbedaan antara harapan 
dan kenyataan para pelanggan atas layanan yang mereka terima". Service Quality dapat diketahui dengan cara membandingkan persepsi pelanggan atas layanan yang benar-benar mereka terima dengan layanan sesungguhnya yang mereka harapkan. Kualitas layanan menjadi hal utama yang diperhatikan serius oleh perusahaan, yang melibatkan seluruh sumber daya yang dimiliki perusahaan.

Tjiptono dan Chandra, (2012), menerangkan bahwa "apabila layanan yang diterima melebihi harapan nasabah, maka kualitas layanan dipersepsikan ideal. Jika pelayanan yang diterima lebih rendah dari pada yang diharapkan, maka kualitas layanan dianggap buruk". Selanjutnya menurut Rangkuti, (2009). "Kualitas layanan pada prinsipnya berfokus pada upaya memenuhi kebutuhan dan keinginan serta ketepatan penyampaianya untuk mengimbangi harapan nasabah".

Mengacu pada pengertian kualitas layanan tersebut maka konsep kualitas layanan adalah suatu daya tanggap dan realitas dari jasa yang diberikan perusahaan. Hal ini berarti bahwa kualitas yang baik bukanlah berdasarkan persepsi penyediaan jasa, melainkan berdasarkan persepsi nasabah.

Menurut Kasmir, (2010), secara umum etiket layanan yang dapat diberikan oleh pegawai bank dalam rangka pelayanan adalah sebagai berikut: 1). "Mengucapkan salam pada saat bertemu dengan nasabah, seperti selamat pagi, selamat siang atau selamat sore. Jika kita sudah tahu agama nasabah, misalnya muslim maka ucapkan assalamualaikum. 2). Setelah mengucapkan salam, segera mempersilahkan nasabah untuk masuk atau duduk dengan sopan atau suruh menunggu sebentar. 3). Baik dalam mengucapkan salam maupun mempersilahkan nasabah masuk atau duduk selalu dengan ramah dan murah senyum. 4). Bertanya tentang keperluan nasabah secara ramah, sopan dan lemah lembut. 5). Biasakan mengucapkan tolong atau maaf saat meminta nasabah mengisi formulir atau menunggu sesaat. 6). Ucapkan kata terima kasih apabila nasabah memberikan saran atau hendak pamit setelah menyelesaikan masalahnya".

Faktor-faktor yang mempengaruhi kualitas layanan. Menurut Parasuraman, et al, (1998) dalam Tjiptono dan Chandra, (2012) untuk mengevaluasi kualitas jasa pelanggan umumnya menggunakan 5 dimensi adalah sebagai berikut: 1). "Bukti fisik; merupakan bukti nyata dari kepedulian dan perhatian yang diberikan oleh penyedia jasa kepada nasabah. Pentingnya dimensi bukti fisik ini akan menumbuhkan image penyedia jasa terutama bagi nasabah baru dalam mengevaluasi kualitas jasa. Perusahaan yang tidak memperhatikan fasilitas fisiknya akan menumbuhkan kebingungan atau bahkan merusak image perusahaan. 2). Keandalan; merupakan kemampuan perusahaan untuk melaksanakan jasa sesuai dengan apa yang telah dijanjikan secara tepat waktu. Pentingnya dimensi ini adalah kepuasan nasabah akan menurun bila jasa yang diberikan tidak sesuai dengan yang dijanjikan. Jadi komponen atau unsur dimensi keandalan ini merupakan kemampuan perusahaan dalam menyampaikan jasa secara tepat dan pembebanan biaya secara tepat. 3). Daya tanggap; merupakan kemampuan perusahaan yang dilakukan oleh langsung karyawan untuk memberikan layanan dengan cepat dan tanggap. Daya tanggap dapat menumbuhkan persepsi yang positif terhadap kualitas jasa yang diberikan. Termasuk didalamnya jika terjadi kegagalan atau keterlambatan dalam penyampaian jasa, pihak penyedia jasa berusaha memperbaiki atau meminimalkan kerugian nasabah dengan segera. Dimensi ini menekankan pada perhatian dan kecepatan karyawan yang terlibat untuk menanggapi permintaan, 
pertanyaan, dan keluhan nasabah. Jadi komponen atau unsur dari dimensi ini terdiri dari kesigapan karyawan dalam melayani nasabah, kecepatan karyawan dalam melayani nasabah, dan penanganan keluhan nasabah. 4). Jaminan; merupakan pengetahuan dan perilaku employee untuk membangun kepercayaan dan keyakinan pada diri nasabah dalam mengkonsumsi jasa yang ditawarkan. Dimensi ini sangat penting karena melibatkan persepsi nasabah terhadap resiko ketidakpastian yang tinggi terhadap kemampauan penyedia jasa. Perusahaan membangun kepercayaan dan kesetiaan nasabah melalui karyawan yang terlibat langsung menangani nasabah. Jadi komponen dari dimensi ini terdiri dari kompetensi karyawan yang meliputi ketrampilan, pengetahuan yang dimiliki karyawan untuk melakukan layanan dan kredibilitas perusahaan yang meliputi hal-hal yang berhubungan dengan kepercayaan nasabah kepada perusahaan seperti, reputasi perusahaan, prestasi dan lain-lain. 5). Empati; merupakan kemampuan perusahaan yang dilakukan langsung oleh karyawan untuk memberikan perhatian kepada nasabah secara individu, termasuk juga kepekaan akan kebutuhan nasabah. Jadi komponen dari dimensi ini merupakan gabungan dari akses yaitu kemudahan untuk memanfaatkan jasa yang ditawarkan oleh perusahaan, komunikasi merupakan kemampuan melakukan untuk menyampaikan informasi kepada nasabah atau memperoleh masukan dari nasabah dan pemahaman merupakan usaha untuk mengetahui dan memahami kebutuhan dan keinginan nasabah".

\section{Kualitas Produk}

Permasalahan kualitas produk adalah sebuah tatangan yang harus dihadapi oleh para perusahaan dan pelaku bisnis apabila tidak ingin kalah dalam pertarungan. Menurut Kotler dan Keller (2012), Kualitas produk adalah "totalitas fitur dan karakteristik produk atau jasa yang bergantung pada kemampuannya untuk memuaskan kebutuhan yang dinyatakan atau tersirat". Sedangkan menurut Assauri (2015), Kualitas produk adalah "pernyataan tingkat kemampuan dari suatu merek atau produk tertentu dalam melaksanakan fungsi yang diharapkan". Menurut The American Society for Quality dalam Kotler dan Amstrong (2012), Kualitas produk adalah "karakteristik produk yang bergantung pada kemampuannya untuk memuaskan kebutuhan pelanggan yang dinyatakan atau tersirat". Menurut ISO 9000 dalam Lupiyoadi (2014), Kualitas produk adalah "degree to which a set of inherent characteristics fulfils requirements" yang artinya kualitas produk adalah "derajat yang dicapai oleh karakteristik yang inheren dalam memenuhi persyaratan". Persyaratan dalam hal ini menurut ISO 9000 adalah "need or expectation that is stated, generally implied or obligatory" yang artinya persyaratan adalah kebutuhan atau harapan yang dinyatakan, biasanya tersirat atau wajib. Jadi, kualitas produk sebagaimana yang diinterpretasikan ISO 9000 merupakan perpaduan antara sifat dan karakteristik yang menentukan sejauh mana keluaran dapat memenuhi persyaratan kebutuhan nasabah. Nasabah yang menentukan dan menilai sampai seberapa jauh sifat dan karakteristik itu memenuhi kebutuhan.

Jadi, dari beberapa definisi para ahli tentang kualitas produk dapat disimpulkan bahwa Kualitas produk adalah keseluruhan ciri, karakteristik dan spesifikasi yang dimiliki suatu barang atau jasa yang bergantung pada kemampuannya untuk memenuhi kebutuhan konsumen.

Dengan menghasilkan produk yang berkualitas baik, ada sejumlah manfaat yang bisa diperoleh perusahaan. Menurut Ariani, (2004) diantaranya: 1). "Pamor Perusahaan Semakin Meningkat; Setelah menghasilkan produk berkualitas, maka 
perusahaan akan mendapatkan predikat perusahaan yang mementingkan kualitas produk sehingga perusahaan akan lebih dikenal serta mendapat nilai lebih dari masyarakat. 2). Biaya yang Dikeluarkan Menurun; Perusahaan tak perlu mengeluarkan biaya lebih untuk menghasilkan suatu produk yang bermutu karena perusahaan berpedoman pada kepuasan pelanggan. 3). Pangsa Pasar Meningkat; Apabila minimasi biaya bisa dicapai maka market share akan meningkat, sebab perusahaan bisa menekan harga meski tetap mengutamakan mutu produk. 4). Produk Akan Dikenal di Pasar Internasional; Jika produk yang ditawarkan memiliki kualitas yang bagus maka produk tidak hanya diterima di pasar domestik tapi juga luar negeri. 5). Perusahaan Akan Lebih Bertanggung Jawab; Dengan adanya kompetisi dari kualitas produk yang diproduksi maka perusahaan lebih dituntut untuk lebih bertanggung jawab di berbagai hal mulai dari rancangan, pembuatan dan penyaluran produk hingga sampai ke tangan konsumen. 6). Meningkatkan Reputasi Produk; Dengan kualitas yang dimiliki sebuah produk maka tidak hanya produknya saja yang terkenal di kalangan masyarakat tapi juga perusahaan yang memproduksinya. 7). Melahirkan Produk Yang Berkualitas; Kompetisi dibidang ekonomi kini bukan tentang harga tapi kualitas produk yang dihasilkan. Hal tersebut akan membuat konsumen membeli produk dengan harga yang tinggi dibarengi kualitas produk yang mumpuni pula".

Persepsi kualitas produk adalah sudut pandang seorang pelanggan mengenai keunggulan produk sesuai keinginan konsumen. Ada 5 jenis persepsi kualitas produk (Tjiptono, 2020), diantaranya yaitu: 1 ). "Transcendental Approach; Dalam pendekatan ini, kualitas bisa diketahui namun sulit diinterpretasikan dan dijalankan. Biasanya, penerapan perspektif ini dilakukan dalam seni seperti drama, musik, tari juga seni rupa. Selain bisa mempromosikan produk mereka dengan pertanyaan seperti kecantikan wajah (kosmetik), kelembutan dan kehalusan kulit (sabun) dan lain sebagainya. 2). Product Based Approach; Pendekatan ini beranggapan bahwa mutu adalah unsur yang bisa dihitung dan diukur. Perbedaan kualitas menggambarkan perbedaan jumlah atribut yang pruk miliki. Perspektif ini sangat objektif, maka tak bisa menjelaskan perbedaan selera, kebutuhan dan pilihan seseorang. 3). User Based Approach; Ini merupakan pendekaran yang bersumber pada perspektif bahwa mutu bergantung pada cara pandang konsumen dan produk yang memenuhi kebutuhan konsumen adalah produk berkualitas tinggi. 4). Sudut pandang yang subjektif dan berorientasi pada permintaan menyatakan bahwa setiap konsumen mempunyai kebutuhan dan keinginan yang berbeda, sehingga banyak pendapat bahwa kualitas sama dengan kepuasan penuh yang diterima. 5). Manufacturing Based Approach; Sudut pandang ini berbasis pasokan dan mencermati praktik perekayasaan, pemanufakturan dan pendefinisian mutu adalah syaratnya. Dalam pendekatan ini berpusat pada penyelarasan spesifikasi yang secara internal dikembangkan dengan tujuan meningkatkan produktivitas dan menekan biaya produksi, sehingga untuk menetapkan kualitas adalah standar perusahaan bukan konsumennya. 6). Value Based Approach; Kualitas dipandang dalam pendekatan ini dari aspek harga dan juga nilainya dengan memperhitungkan menjual antara kemampuan dan harga, mutu diartikan sebagai keunggulan keterjangkauan. Dalam sudut pandang ini, kualitas bersifat relatif sehingga belum tentu produk berkualitas tinggi adalah produk paling bernilai karena yang paling bernilai adalah produk yang dibeli dengan tepat". 
Menurut Garvin yang dikutip Tjiptono (2020) kualitas produk memiliki delapan indikator sebagai berikut: 1). "Kinerja (performance), hal ini berkaitan dengan aspek fungsional suatu barang dan merupakan karakteristik utama yang dipertimbangkan pelanggan dalam membeli barang tersebut.

2).

Keistimewaan tambahan (Featurs), yaitu performansi yang berguna untuk menambah fungsi dasar, berkaitan dengan pilihan-pilihan produk dan pengembangannya. 3). Kehandalan (Reliability), hal yang berkaitan dengan probabilitas atau kemungkinan suatu barang berhasil menjalankan fungsinya setiap kali digunakan dalam periode waktu tertentu dan dalam kondisi tertentu pula. 4). Kesesuaian spesifikasi (Conformance), hal ini berkaitan dengan tingkat kesesuaian terhadap spesifikasi yang telah diterapkan sebelumnya berdasarkan keinginan pelanggan. 5). Daya tahan (Durability), yaitu suatu refleksi umur ekonomis berupa ukuran daya tahan atau masa pakai barang. 6). Pelayanan (Serviceability), yaitu karakteristik yang berkaitan dengan kecepatan, kompetensi, kemudahan, dan akurasi dalam memberikan layanan untuk perbaikan barang. 7). Esttika (Ashtetics), merupakan karakteristik yang bersifat subyektif mengenai nilai-nilai estetika yang berkaitan dengan pertimbangan pribadi dan refleksi dari preferensi individual. 8). Persepsi terhadap kualitas (Perceived quality), konsumen tidak selalu memiliki informasi yang lengkap mengenai atribut-atribut produk. Namun demikian, biasanya konsumen memiliki

akan diteliti, persyaratan minimum untuk dapat dikatakan valid adalah $r=0,30$. Jadi, apabila korelasi antara butir-butir item pernyataan dengan skor total kurang dari 0,30, maka butiran dalam instrumen tersebut dapat dikatakan tidak valid. Uji validitas dilakukan dengan melihat korelasi antara skor masing-masing item informasi tentang produk secara tidak langsung".

\section{METODE PENELITIAN}

Penelitian ini termasuk dalam kategori penelitian asosiatif kausal dengan menggunakan pendekatan kuantitatif. Populasi dalam penelitian ini adalah seluruh nasabah Bank Tabungan Negara Cabang Karawang dengan kriteria berusia minimal 17 tahun, dengan sampel berjumlah 80 orang dengan teknik sampling insidental. Metode analisa data dengan menggunakan regresi linear sederhana dan berganda.

\section{HASIL PENELITIAN DAN PEMBAHASAN}

\section{Hasil Penelitian}

\section{Uji instrumen data}

Berdasarkan uraian tersebut di atas, maka untuk dapat menentukan apakah variabel kualitas layanan dan kualitas produk dapat dijadikan pengukur terhadap kepuasan nasabah Bank Tabungan Negara Cabang Karawang. Namun sebelumnya data diolah terlebih dahulu dan dilakukan pengujian terhadap varibel yang digunakan yaitu kualitas layanan, kualitas produk dan kepuasan nasabah untuk mengetahui data tersebut akurat dan dapat dipercaya.

\section{Uji validitas}

Pengujian validitas ini dilakukan untuk menguji apakah tiap butir pernyataan telah mewakili indikator yang pernyataan dengan skor total. (Sugiyono, 2017).

Dari perhitungan koefisien korelasi skor tiap butir pernyataan dari 80 responden tentang instrumen kualitas layanan, dengan jumlah 10 butir pernyataan; instrumen kualitas produk 10 butir pernyataan dan instrumen kepuasan nasabah 8 butir pernyataan dengan total 
skor setiap responden diperoleh hasil $\mathrm{r}$ hitung lebih besar dari $\mathrm{r}$ kritis $=0,30$, maka seluruh item pernyataan didapatkan hasil yang valid.

\section{Uji reliabilitas}

Pengujian reliabilitas ini dilakukan untuk menguji seberapa jauh hasil pengukuran yang dapat diandalkan secara konsisten. Pada tabel 1 hasil pengujian reliabilitas berikut, diketahui bahwa semua variabel mempunyai alpha di atas 0,6 yang berarti bahwa semua variabel dalam penelitian ini dapat diandalkan.

Tabel 2: Hasil Uji Reliabilitas

\begin{tabular}{lccc}
\hline \multicolumn{1}{c}{ Variabel } & $\begin{array}{c}\text { Cronbach } \\
\text { Alpha }\end{array}$ & $\begin{array}{c}\text { Nilai kritis } \\
(\boldsymbol{\alpha})=\mathbf{5 \%}\end{array}$ & Keterangan \\
\hline Kualitas Layanan & 0.858 & 0.800 & Reliabel \\
Kualitas Produk & 0.770 & 0.800 & Reliabel \\
Kepuasan Nasabah & 0.741 & 0.800 & Reliabel \\
\hline
\end{tabular}

Sumber: Data Primer, diolah tahun 2021

Berdasarkan angka-angka reliabilitas cronbach alpha tersebut tampak bahwa seluruh pernyataan yang ada membentuk ukuran yang reliabel dari mulai kualitas layanan, kualitas produk, dan kepuasan nasabah membentuk ukuran yang reliabel dari masing-masing variabel.

\section{Analisis regresi linear sederhana}

Tabel 3: Pengaruh Kualitas Layanan Terhadap Kepuasan Nasabah BTN Cabang Karawang

\begin{tabular}{lcccccc}
\hline \multirow{2}{*}{ Variabel } & $\mathbf{R}$ & $\begin{array}{c}\mathbf{R} \\
\text { Square }\end{array}$ & Konstanta & $\begin{array}{c}\text { Koefisien } \\
\text { Regresi }\end{array}$ & Sig & $\boldsymbol{\alpha}$ \\
\cline { 2 - 7 } & 0,863 & 0,745 & 8,510 & 0,611 & 0,000 & 0,01 \\
\hline Kualitas Layanan & 0,80 & & & & \\
\hline Pengujian Signifikan & & & & \\
\hline t hitung > t tabel = 15,113 > 1,991 & & & & \\
\hline Keterangan: Variabel Kepuasan Nasabah \\
Sumber: data diolah 2021
\end{tabular}

Berdasarkan Tabel 3, nilai koefisien determinasi $\left(R^{2}\right)$ sebesar 0.745 , artinya kualitas layanan memberikan kontribusi sebesar 74,5\% kepada kepuasan nasabah Bank Tabungan Negara Cabang Karawang, sedangkan sisanya sebesar $25,5 \%$ disumbangkan faktor lain yang tidak diteliti.

Persamaan regresi

$$
\mathrm{Y}=8,510+0,611\left(\mathrm{X}_{1}\right)
$$

Kualitas layanan berpengaruh positif dan signifikan pada tingkat nyata 99\% terhadap kepuasan nasabah Bank Tabungan Negara Cabang Karawang. Koefisien kualitas layanan sebesar 0,611, artinya jika ada peningkatan kualitas layanan, maka kepuasan nasabah Bank Tabungan Negara Cabang Karawang akan meningkat.

\section{Tabel 4: Peran Kualitas Produk Terhadap Kepuasan Nasabah BTN Cabang Karawang}




\begin{tabular}{lcccccc}
\hline \multirow{2}{*}{ Variabel } & $\mathbf{R}$ & $\begin{array}{c}\mathbf{R} \\
\text { Square }\end{array}$ & Konstanta & $\begin{array}{c}\text { Koefisien } \\
\text { Regresi }\end{array}$ & Sig & $\boldsymbol{\alpha}$ \\
\cline { 2 - 7 } & 0,808 & 0,653 & 2,603 & 0,748 & 0,000 & 0.01 \\
\hline Kualitas Produk & 0,803 & & & & \\
\hline Pengujian Signifikan & & & &
\end{tabular}

Keterangan: Variabel Kepuasan Nasabah

Sumber: data diolah 2021

Berdasarkan Tabel 4, nilai koefisien determinasi $\left(R^{2}\right)$ sebesar 0.653 , artinya kualitas produk memberikan kontribusi sebesar 65,3\% kepada kepuasan nasabah Bank Tabungan Negara Cabang Karawang, sedangkan sisanya sebesar $34,7 \%$ disumbangkan faktor lain yang tidak diteliti.

Persamaan regresi
$\mathrm{Y}=2,603+0,748\left(\mathrm{X}_{2}\right)$

Kualitas produk berpengaruh positif dan signifikan pada tingkat nyata $99 \%$ terhadap kepuasan nasabah Bank Tabungan Negara Cabang Karawang. Koefisien kualitas produk sebesar 0,748, artinya jika ada peningkatan kualitas produk, maka kepuasan nasabah Bank Tabungan Negara Cabang Karawang akan meningkat.

\section{Analisis regresi linear berganda}

Tabel 5: Peran Kualitas Layanan dan Kualitas Produk Terhadap Kepuasan Nasabah BTN Cabang Karawang

\begin{tabular}{lcccccc}
\hline \multirow{2}{*}{ Variabel } & $\begin{array}{c}\text { Mult. } \\
\text { R }\end{array}$ & $\begin{array}{c}\mathbf{R} \\
\text { Square }\end{array}$ & Konstanta & $\begin{array}{c}\text { Koef. } \\
\text { Regresi }\end{array}$ & Sig. & $\boldsymbol{\alpha}$ \\
\hline $\begin{array}{l}\text { Kualitas Layanan } \\
\text { Kualitas Produk }\end{array}$ & 0,882 & 0,778 & 4,042 & 0,431 & 0,000 & 0,01 \\
\hline Pengujian Signifikan & & & & 0,288 & 0,000 & 0,000 \\
\hline F hitung > F tabel = 134,801 > 3,115 & & & & \\
\hline
\end{tabular} $\begin{aligned} & \text { Keterangan: Variabel Kepuasan Nasabah } \\
& \text { Sumber: data diolah 2021 }\end{aligned}$

Berdasarkan Tabel 5, nilai $\mathrm{F}$ hitung 134,801 , artinya ada pengaruh signifikan kualitas layanan dan kualitas produk terhadap kepuasan nasabah Bank Tabungan Negara Cabang Karawang. Nilai koefisien determinasi $\left(R^{2}\right)$ sebesar 0.778, artinya kualitas layanan dan kualitas produk secara bersama-sama memberikan kontribusi sebesar 77,8\% kepada kepuasan nasabah Bank Tabungan Negara Cabang Karawang, sedangkan sisanya sebesar 22,2\% disumbangkan faktor lain yang tidak dibahas dalam penelitian ini.
Persamaan regresi

$\mathrm{Y}=4,042+0,431\left(\mathrm{X}_{1}\right)+0,288\left(\mathrm{X}_{2}\right)$

Kualitas Layanan dan kualitas produk berpengaruh signifikan terhadap kepuasan nasabah Bank Tabungan Negara Cabang Karawang, pada tingkat nyata 99\%. Koefisien kualitas layanan sebesar 0,431, artinya jika ada peningkatan kualitas layanan, maka kepuasan nasabah Bank Tabungan Negara Cabang Karawang akan meningkat atau 
sebaliknya dengan asumsi kualitas produk tidak berubah. Koefisien kualitas produk sebesar 0,288, artinya jika ada peningkatan kualitas produk, maka kepuasan nasabah Bank Tabungan Negara Cabang Karawang, akan meningkat atau sebaliknya, dengan asumsi kualitas layanan tidak berubah.

\section{Pembahasan}

Pengaruh kualitas layanan terhadap kepuasan nasabah Bank Tabungan Negara Cabang Karawang

Hasil penelitian ini menunjukkan bahwa kualitas layanan yang baik dapat mendorong peningkatan kepuasan nasabah Bank Tabungan Negara Cabang Karawang. Hal ini dikarenakan bahwa pada karyawan berpenampilan rapih, sopan, menarik, bahan yang berkaitan dengan jasa terlihat menarik, karyawan memberikan layanan sesuai dengan yang diharapkan nasabah, handal dalam menangani masalahnya nasabah, cepat tanggap dalam penanganan keluhan nasabah, mampu berkomunikasi dengan baik pada nasabah, dapat menanamkan kepercayaan pada nasabah, terjaminnya keamanan dalam bertransaksi, karyawan menghadapi naabah dengan penuh perhatian, dan karyawan memiliki pemahaman terhadap kebutuhan nasabah secara spesifik. Hasil penelitian ini sesuai dengan penelitian yang dilakukan oleh Dewi dan Sudiartha. (2018) dan Assegaff (2016), yaitu menganalisis pengaruh kualitas layanan terhadap kepuasan nasabah Bank. Dengan demikian hipotesis pertama diterima.

\section{Pengaruh kualitas produk terhadap kepuasan nasabah Bank Tabungan Negara Cabang Karawang}

Hasil penelitian ini menunjukkan bahwa kualitas produk Bank Tabungan Negara dapat mendorong peningkatan kepuasan nasabah Bank Tabungan Negara Cabang Karawang. Hal ini dikarenakan bahwa kinerja produk merupakan karakteristik yang utama, pilihan produk dapat dikembangkan, produknya dapat digunakan dalam periode waktu tertentu, produk tabungan sesuai dengan keinginan nasabah, produknya terjamin, memiliki ukuran daya tahan atas produk tersebut, pelayanan yang diberikan atas produk sesuai keinginan nasabah, produk yang ditawarkan menarik dan beragam, nasabah memiliki informasi lengkap mengenaiatribut produk. Hasil penelitian ini sejalan dengan penelitian yang dilakukan oleh Indarto, et al (2015), dan Sitanggang, et al. (2019), yaitu menganalisis Pengaruh Kualitas Produk Terhadap Kepuasan Nasabah Bank. Dengan demikian hipotesis kedua diterima.

\section{Pengaruh kualitas layanan dan kualitas produk terhadap kepuasan nasabah Bank Tabungan Negara Cabang Karawang}

Berdasarkan hasil analisis diketahui bahwa kualitas layanan dan kualitas produk dapat mendorong peningkatan kepuasan nasabah Bank Tabungan Negara Cabang Karawang. Hasil penelitian ini sama dengan hasil penelitian yang dilakukan oleh Dewi dan Sudiartha (2018), dan Tanuwijaya, (2013), Endarwinata, (2013) dan yaitu menganalisis Pengaruh Kualitas layanan dan kualitas produk Terhadap Kepuasan nasabah Bank. Dengan demikian hipotesis ketiga diterima.

\section{KESIMPULAN DAN SARAN}

\section{Kesimpulan}

Berdasarkan hasil pembahasan dapat ditarik beberapa kesimpulan sebagai berikut: 1). Kualitas layanan mendorong peningkatan kepuasan nasabah Bank Tabungan Negara Cabang Karawang. Hasil penelitian ini menunjukkan bahwa semakin tinggi kualitas layanan yang diberikan BTN Cab. Karawang maka 
semakin tinggi kepuasan yang dirasakan nasabah terhadap layanan. 2). Kualitas produk mendorong peningkatan kepuasan nasabah Bank Tabungan Negara Cabang Karawang. Hasil penelitian ini menunjukkan bahwa semakin tinggi kualitas produk yang ditawarkan BTN Cab. karwang maka semakin tinggi kepuasan yang dirasakan nasabah terhadap produk. 3). Kualitas layanan dan kualitas produk mendorong peningkatan kepuasan nasabah Bank Tabungan Negara Cabang Karawang. Hasil penelitian ini menunjukkan bahwa apabila BTN Cab. Karawang memberikan dan menawarkan layanan dan produk yang berkualitas tinggi maka kepuasan nasabah akan tinggi sehingga nasabah akan bertahan dalam menggunakan produk dan layanan yang diberikan BTN Cab. Karawang.

\section{Saran}

Berdasarkan hasil analisis dan kesimpulan, maka saran yang dapat diberikan kepada pihak-pihak yang memerlukan adalah: 1). Bagi BTN Cab. Karawang; Kualitas layanan dan kualitas produk yang baik akan meningkatkan kepuasan nasabah. Kedua hal ini tidak dapat dipisahkan, untuk itu BTN Cab. Karawang harus lebih memperhatikan kualitas layanan dan kualitas produk yang mereka berikan. 2). Bagi Akademis; Hasil penelitian ini dapat dijadikan tambahan referensi, khususnya yang membahas tentang kualitas layanan dan kualitas produk terhadap kepuasan nasabah bank. 3). Peneliti selanjutnya; Sedapat mungkin melakukan pengembangan penelitian dengan menambah variabel-variabel lain yang belum dibahas dalam penelitian ini yang berkaitan dengan masalah kepuasan nasabah bank.

\section{DAFTAR PUSTAKA}

Antonio, M. Syafi'i. 2001. Bank Islam: Teori dan Praktik. Jakarta: Gema Insani Press.
Ariani, Dorothea Wahyu. 2004. Manajemen Kualitas: Pendekatan Sisi Kualitatif. Jakarta: Ghalia Indonesia.

Assauri, Sofjan. 2015. Manajemen Pemasaran. Jakarta: Rajawali Pers.

Assegaff, Setiawan. 2016. "The Effect of Service Quality to Customer Satisfaction by Using Internet Banking Service in Jambi". The Asian Journal of Technology Management Vol. 9 No. 1 (2016): 21-36.

Bellbie, Richarrd Sellasie. 2012. The Impact of Internet Banking Service Quality on Customer Satisfaction in The Banking Sector of Ghana. Journal of marketing

Dewi, Cokorda Istri Agung Krisna dan Sudiartha, I Gede Merta. 2018. "Pengaruh Kualitas Layanan dan Kualitas Produk Terhadap Kepuasan Nasabah PT. Bank Pembangunan Daerah Bali”. EJurnal Manajemen Unud, Vol. 7, No. 8, 2018: 4539- 4569 ISSN: 2302-8912. DOI: https://doi.org/10.24843/EJMUNU D.2018.v7.i08.p18.

Endarwinata. 2013. "Pengaruh Kualitas Produk dan Kualitas Pelayanan Terhadap Kepuasan dan Loyalitas Nasabah Tabungan Bank BRI Cabang Simpang Empat". EJournal Apresiasi Ekonomi Volume 1, Nomor 3, September 2013: 167180. ISSN: 2337-3997.

Garvin, D.A. 1994. Kualitas Produk: Alat Strategi Yang Penting. Free Press.

Helza, Vebrika ST. 2007. "Pengaruh Kualitas Jasa Internet Banking Terhadap Kepuasan Konsumen. Thesis. Universitas Gunadarma Jakarta.

Indarto, Erik Wahyu., Suroso, Imam., Sudaryanto dan Qomariah, Nurul. 2015. "The Effect of Brand Image and Product Attributes on Customer 
Satisfaction and Customer Loyalty". Journal of Applied Management (JAM) Volume 16 Number 3,September 2018 Indexed in Google Scholar.

Kasmir. 2010. Pemasaran Bank. Jakarta: Kencana.

Kotler, Philip. 2008. Prinsip-prinsip Pemasaran. Jilid I. Jakarta: Erlangga.

Kotler, Philip dan Amstrong, Gary. 2012. Principles of Marketing. 15th Edition, Pearson Education Limited. Kotler, dan Keller. 2012. Manajemen Pemasaran. Edisi 12. Jakarta: Erlangga.

Lupiyoadi, Hamdani. 2014. Manajemen Pemasaran Jasa. Jakarta: Salemba Empat.

Maharsi, Sri dan Fenny. 2006. Analisa Faktor-Faktor yang Mempengaruhi Kepercayaan dan Pengaruh Kepercayaan Terhadap Loyalitas Pengguna Internet Banking di Surabaya. Jurnal Akuntansi dan Keuangan Vol. 8, NO. 1, MEI 2006: 35-51

Parasuraman, A., V. A. Zeithaml, dan L.L. Berry, 1998, SERVQUAL: A Multiple-Item Scale for Measuring Consumer Perceptions of Service Quality, Journal of Retailing, Vol. 64, No. 1.

Rangkuti, Freddy. 2009. Measuring Customer Satisfaction. Jakarta: PT Gramedia Pustaka Utama.

Sitanggang, Juwita Magdalena., Sinulingga, Sukaria dan FAchruddin, Khaira Amalia. 2019.
"Analysis of The Effect of Product Quality on Customer Satisfaction and Customer Loyalty of Indihome ATPT Telkom Regional 1 Sumatera, Medan, North Sumatra, Indonesia". American International Journal of Business Management (AIJBM) ISSN- 2379-106X, www.aijbm.com Volume 2, Issue 3 (March - 2019), PP 26-37.

Sugiyono. 2017. Statikstika Untuk Penelitian. Bandung. Penerbit Alfabeta.

Sutabri, Tata. 2012. Analisis Sistem Informasi. Yogyakarta: Andi.

Swasta, Basu, dan Irawan. 2008. Manajemen Pemasaran Modern. Yogyakarta: Liberty.

Tanuwijaya, Melissa dan Anshori, Mohamad Yusak. 2013. "Pengaruh Kualitas Layanan dan Kualitas Produk Terhadap Kepuasan Pelanggan Pipop Copy". Jurnal $\mathrm{NeO}$-Bis. Volume 7, No. 1, Juni 2013. Hal. 1-16

Tjiptono, Fandy. 2020. Strategi Pemasaran Prinsip dan Penerapan. Yogyakarta: Andi.

Tjiptono, Fandy dan Gregorius Chandra, 2012, Pemasaran Strategik. Yogyakarta, Andi.

Yamit, Zulian. 2013. Manajemen Kualitas Produk dan Jasa. Yogyakarta: Ekonisia.

Zeithaml, V.A. Parasuraman, A. and L. Berry L. 1985. "Problems and Strategies in Services Marketing". Jurnal of Marketing Vol. 49. (Spring). 